\title{
Reduced CD40L Expression on ex vivo Activated CD4+ T-Lymphocytes from Patients with Excellent Renal Allograft Function Measured with a Rapid Whole Blood Flow Cytometry Procedure
}

\author{
Stephan R. Lederer Nicole Friedrich Rudolf Gruber Rüdiger Landgraf \\ Marcel Toepfer Thomas Sitter
}

Medizinische Klinik, Innenstadt, Klinikum der Universität München, München, Deutschland

\section{Key Words}

CD40L · Costimulatory molecules $\cdot$ Renal transplantation - Chronic allograft dysfunction . Flow cytometry

\begin{abstract}
Background: The CD40-CD40L (CD154) costimulatory pathway plays a critical role in the pathogenesis of kidney allograft rejection. In renal transplant biopsies, CD4+CD40L+ graft-infiltrating cells were detected during chronic rejection in contrast to acute rejection episodes. Using a rapid noninvasive FACS procedure, we were able to demonstrate $\mathrm{CD} 40 \mathrm{~L}$ upregulation in peripheral blood of patients with chronic renal allograft dysfunction. Materials and Methods: Whole blood from recipients of renal allografts was stimulated with PMA and ionomycin and measured by flow cytometry. Patients were assigned to three groups based on transplant function. Group 1: 26 patients with excellent renal transplant function; group 2: 28 patients with impaired transplant function; group 3: 14 patients with chronic allograft dysfunction and group 4: 8 healthy controls. Results: The median percentage \pm SEM of CD4+/CD40L+ cells stimulated ex vivo at $10 \mathrm{ng} / \mathrm{ml}$ PMA was as follows: group 1: $28.3 \pm$ 4.1\%; group 2: $18.4 \pm 2.4 \%$; group 3: $50.1 \pm 5.0 \%$ and group 4: $40.4 \pm 3.4 \%$. Subdivisions of groups 2 and 3
\end{abstract}

\section{KARGER}

Fax + 41613061234 E-Mail karger@karger.ch www. karger.com

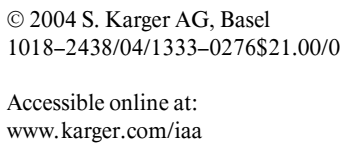

resulted in different CD40L expression patterns. Patients with increased serum creatinine since the initial phase after transplantation (groups $2 \mathrm{a}$ and $3 \mathrm{a}$ ) revealed a higher percentage of CD4+CD40L+ cells than patients showing a gradual increase over time (groups $2 \mathrm{~b}$ and $3 \mathrm{~b}$ ). Consequently, patients of group $3 a$ exhibited a significantly reduced transplant function compared with those of group 3b. Conclusion: After PMA + ionomycin stimulation, patients with excellent kidney graft function displayed significantly reduced expression of CD40L surface molecules on CD4+ cells early after transplantation. Those with a chronic dysfunction of the renal graft showed significantly more CD4+ cells expressing CD40L compared to the other transplanted groups. These results demonstrate that the percentage of CD4+CD40L+ cells stimulated ex vivo in peripheral blood may be a valuable marker for chronic allograft nephropathy.

Copyright @ 2004 S. Karger AG, Basel

\section{Introduction}

Despite improvements in 1-year allograft survival, the long-term results of kidney transplantation remain unsatisfactory with an average half-life of approximately 14 years. A multitude of risk factors has been defined and correlated with allograft failure. One major reason for ear-
Correspondence to: Dr. Stephan R. Lederer

Medizinische Klinik - Innenstadt, Klinikum der Universität München Ziemssenstrasse 1

DE-80336 Munich (Germany)

Tel. +49 8951602111, Fax +49 8951739989, E-Mail ledererdr@aol.com 
ly graft loss is persistent immunological stress. To date, the underlying pathological mechanisms of this condition are incompletely understood. Intimal thickening of vessels, tubular atrophy, glomerulosclerosis and interstitial fibrosis are unspecific histopathologic features of chronic allograft nephropathy, which are similar to those of atherosclerotic lesions.

In general, renal allografts are rejected as a result of an immune response directed at alloantigens expressed on the graft. In this respect, the role of HLA antigens is well established. Various investigators have demonstrated that early and late acute rejection episodes represent major causes of chronic graft dysfunction and subsequent graft loss. Apart from immunological processes, nonimmunological risk factors account for chronic allograft dysfunction as well. Putative nonimmunological risk factors include donor age, donor source (living or cadaveric), cold ischemia time, delayed graft function, size mismatch, donor and recipient gender, recipient race, hyperlipidemia and hypertension [1].

The mechanisms by which these clinical risk factors damage the nephron are not known. Differential intragraft gene expression of cytokines, chemokines and their receptors as well as cytotoxic attack molecules was detected during acute rejection episodes [2, 3]. Nonetheless, only few data have been published on the role of these molecules in chronic graft dysfunction. A strong correlation between TGF- $\beta$ mRNA expression and the extent of interstitial fibrosis, a hallmark of chronic rejection has been described. Hyperexpression of TGF- $\beta_{1}$ is thought to coincide with chronic allograft nephropathy [4].

More interestingly, a differential expression pattern of costimulatory molecules has been detected by immunohistological staining during acute and chronic rejection episodes in renal biopsies. In this respect, the CD28/ CTLA-4-B7 pathway appears to be involved mainly in acute rejection episodes, whereas the CD40-CD40L pathway seems to be predominant in chronic renal allograft rejection $[5,6]$. The interaction between the B7-1 and B72 receptors, expressed on the surface of antigen-presenting cells (APC), and their counter-receptors CTLA-4 and CD28 presented on T-cells triggers a decisive costimulatory signal for T-lymphocytes that acts in concert with the interaction between MHC-II and TCR-CD3 [7, 8]. T-lymphocyte stimulation by B7-1 and B7-2 and by antigen recognition induces the expression of the surface molecule CD40L, a $39-\mathrm{kD}$ type II membrane glycoprotein expressed mainly on activated CD4+ T-cells, but also on a small population of CD8+ T-lymphocytes at a low density [9]. Additionally, it is also found on human dendritic cells
[10], macrophages [11], tissue mast cells, blood basophils [12], eosinophils [13] and in kidney tissue in inflammatory renal disease $[14,15]$. CD40L binds to CD40 present on B-cells, dendritic cells, activated macrophages and endothelial cells and thereby activates the immune system. Thus CD40-CD40L interactions play a critical role in the immunologic response. Experimental blockade of ligation prevents $\mathrm{T}$-and B-cell activation and induces long-term allograft survival [16-18].

The aim of our study was to measure CD40L expression on peripheral CD4+ T-cells stimulated ex vivo in recipients with either excellent function or chronic dysfunction of their renal allografts. In order to determine this upregulation of CD40L on peripheral blood cells, a FACS analysis procedure was developed.

\section{Materials and Methods}

\section{Patients}

This study included 68 patients (41 males, 27 females, mean age $48.5 \pm 10.0$ years), 22 recipients of cadaver kidney transplants (15 males, 7 females, mean age $55.1 \pm 11.5$ years) and 46 recipients of simultaneous kidney/pancreas transplants (26 males, 20 females, mean age $45.3 \pm 7.3$ years). The underlying renal diseases were as follows: diabetes mellitus $(n=47)$, glomerulonephritis $(n=8)$, polycystic kidney disease $(n=6)$, interstitial nephritis $(n=4)$, analgetic nephropathy $(\mathrm{n}=1)$, kidney atrophy $(\mathrm{n}=1)$ and 1 undefined cause. Immunosuppression consisted of cyclosporin $\mathrm{A}(\mathrm{C})$ alone, in combination with mycophenolate mofetil (M), azathioprine (A), steroids (S) or tacrolimus (T) in combination with mycophenolate mofetil, azathioprine and steroids. The following regimens were applied: $13 \times \mathrm{C}$ monotherapy; $10 \times \mathrm{C} / \mathrm{A} ; 4 \times \mathrm{C} / \mathrm{A} / \mathrm{S} ; 14 \times \mathrm{C} / \mathrm{M} ; 7 \times \mathrm{C} / \mathrm{M} / \mathrm{S}$; $1 \times \mathrm{C} / \mathrm{S} ; 2 \times \mathrm{T} / \mathrm{A} ; 12 \times \mathrm{T} / \mathrm{M} ; 1 \times \mathrm{T} / \mathrm{S} 1 \times \mathrm{T} / \mathrm{A} / \mathrm{S}, 1 \times \mathrm{T} / \mathrm{M} / \mathrm{S}$ and $2 \times \mathrm{M} / \mathrm{S}$. The mean dosage of immunosuppressants is shown in table 1. Eight healthy volunteers ( 4 males, 4 females, mean age 49.2 \pm 12.4 years) without clinical or laboratory signs of kidney disease served as controls.

Patients were assigned to three groups based merely on serum creatinine (s-crea) levels. Group 1 consisted of 26 patients with excellent renal transplant function ascertained by a stable s-crea of $1.2 \mathrm{mg} / \mathrm{dl}$ or less for the whole transplantation period. Group $2 \mathrm{com}-$ prised 28 recipients with impaired transplant function expressed by s-crea between 1.5 and $2.4 \mathrm{mg} / \mathrm{dl}$ when included in the study and a $\mathrm{s}$-crea of $\leq 1.8 \mathrm{mg} / \mathrm{dl}$ within the first 6 months after transplantation. Group 3 included 14 patients with consistently elevated s-crea levels of $\geq 2.0 \mathrm{mg} / \mathrm{dl}$ defined as chronic allograft dysfunction. Healthy controls $(n=8)$ were assigned to group 4 (table 2$)$.

None of the patients showed signs of acute rejection of the renal and/or the pancreatic graft at the time of examination. In order to exclude inflammatory reactions, the serum levels of c-reactive protein (CRP) were measured using a highly sensitive assay. Patients with values higher than $0.5 \mathrm{mg} / \mathrm{dl}$ were excluded from the study. No evidence of bacterial or viral infections was observed when blood samples were taken (table 3). 
Table 1. Mean $( \pm \mathrm{SEM})$ dosage of immunosuppressants $(\mathrm{mg} / \mathrm{kg}$ body weight/day; number of patients in parentheses)

\begin{tabular}{llllll}
\hline Group & Cyclosporin A & $\begin{array}{l}\text { Mycophenolate } \\
\text { mofetil }\end{array}$ & Azathioprine & Tacrolimus & Steroids \\
\hline 1 & $3.15 \pm 0.94(15)$ & $18.85 \pm 7.49(12)$ & $0.80 \pm 0.14(5)$ & $64.52 \pm 23.87(10)$ & $0.16 \pm 0.14(6)$ \\
1.1 & $3.00 \pm 0.41(6)$ & $19.20 \pm 8.31(9)$ & $0.90 \pm 0.08(2)$ & $66.57 \pm 24.32(9)$ & $0.11 \pm 0.05(2)$ \\
1.2 & $3.22 \pm 1.10(9)$ & $17.93 \pm 4.53(3)$ & $0.73 \pm 0.13(3)$ & $46.15 \pm 0.00(1)$ & $0.19 \pm 0.16(4)$ \\
2 & $2.94 \pm 0.88(23)$ & $21.16 \pm 7.10(14)$ & $0.67 \pm 0.28(10)$ & $56.23 \pm 6.07(5)$ & $0.03 \pm 0.01(4)$ \\
$2 \mathrm{a}$ & $2.93 \pm 0.92(12)$ & $22.64 \pm 7.45(7)$ & $0.59 \pm 0.18(7)$ & $55.59 \pm 6.63(4)$ & $0.03 \pm 0.01(3)$ \\
$2 \mathrm{~b}$ & $2.96 \pm 0.82(11)$ & $19.43 \pm 6.24(7)$ & $0.85 \pm 0.38(3)$ & $58.82 \pm 0.00(1)$ & $0.04 \pm 0.00(1)$ \\
3 & $2.64 \pm 1.23(11)$ & $14.31 \pm 5.36(10)$ & $0.73 \pm 0.10(2)$ & $78.50 \pm 22.95(2)$ & $0.10 \pm 0.13(7)$ \\
$3 \mathrm{a}$ & $2.01 \pm 0.45(5)$ & $16.31 \pm 2.30(5)$ & $(0)$ & $101.45 \pm 0.00(1)$ & $0.04 \pm 0.02(3)$ \\
$3 \mathrm{~b}$ & $3.06 \pm 1.39(6)$ & $12.70 \pm 6.46(5)$ & $0.73 \pm 0.10(2)$ & $55.56 \pm 0.00(1)$ & $0.14 \pm 0.16(4)$ \\
\hline
\end{tabular}

Table 2. Patient demographics of the renal transplant groups (mean $\pm \mathrm{SD}$ )

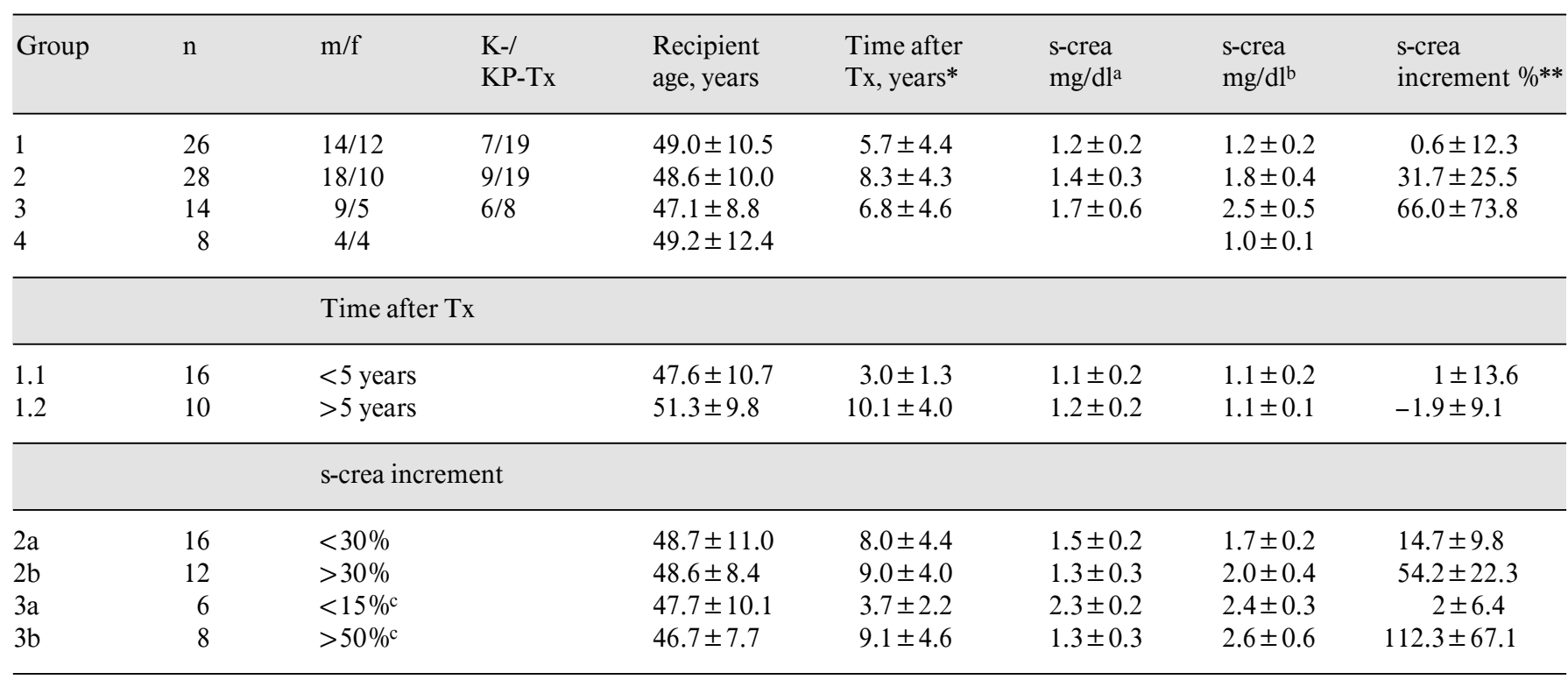

a Measured after a follow-up of 6 months after transplantation.

b Measured on the day of study.

c There were no patients with s-crea increments between 15 and $50 \%$.

p values: * time after Tx: 1 versus 2, $2 \mathrm{a}$ versus $3 \mathrm{a}, 3 \mathrm{a}$ versus $3 \mathrm{~b}$ and $2 \mathrm{~b}$ versus $3 \mathrm{a}(<0.05)$; ${ }^{* *}$ s-crea increment: 1 versus 2 , 1 versus 3 , 2a versus $3 a$ and $2 b$ versus $3 b(<0.0005)$, $2 a$ versus $2 b$, $3 a$ versus $3 b, 2 b$ versus $3 a$ and $2 a$ versus $3 b(<0.005)$.

\section{Stimulation of T-Cells in Whole Blood}

For the determination of CD40L cell surface expression, lithium heparin anticoagulated peripheral blood (not older than $5 \mathrm{~h}$ ) was stimulated with calcium ionophore A23187 (ionomycin, hemicalcium salt, $300 \mathrm{ng} / \mathrm{ml}$ final concentration, Sigma, Deisenhofen, Germany) and various concentrations of phorbol-12-myristate-13-acetate (PMA; Sigma). $800 \mu 1$ ionomycin containing RPMI-1640 (+Lglutamine, Life Technologies, Paisley, UK) was prepared per well (24-well cell culture cluster, FB, Corning, N.Y., USA). PMA was added at the following final concentrations: $0,2,4,5,7.5,10,20,30,50$ and $100 \mathrm{ng} / \mathrm{ml} .200 \mu \mathrm{l}$ of whole blood was added to each well and incubated for $4 \mathrm{~h}$ at $37^{\circ} \mathrm{C}$ in $5 \% \mathrm{CO}_{2}$. After thorough washing $(0.5 \%$ BSA/PBS, Paesel + Lorei, Hanau, Germany), cells were labeled with the following monoclonal antibody preparations (PharMingen, Heidelberg, Germany, $2 \mu$ each): anti-CD40L-PE (TRAP-1), CD8-FITC (RPA-T8) and CD3-APC (UCHT1) at room temperature in the dark for $20 \mathrm{~min}$. The red blood cells were lysed by FACSlyse (Becton Dickinson, Heidelberg, Gemany), washed and lysed again when necessary. After washing, cells were fixed in $1 \%$ paraformaldehyde/PBS and stored overnight at $4{ }^{\circ} \mathrm{C}$ pending analysis by flow cytometry. 

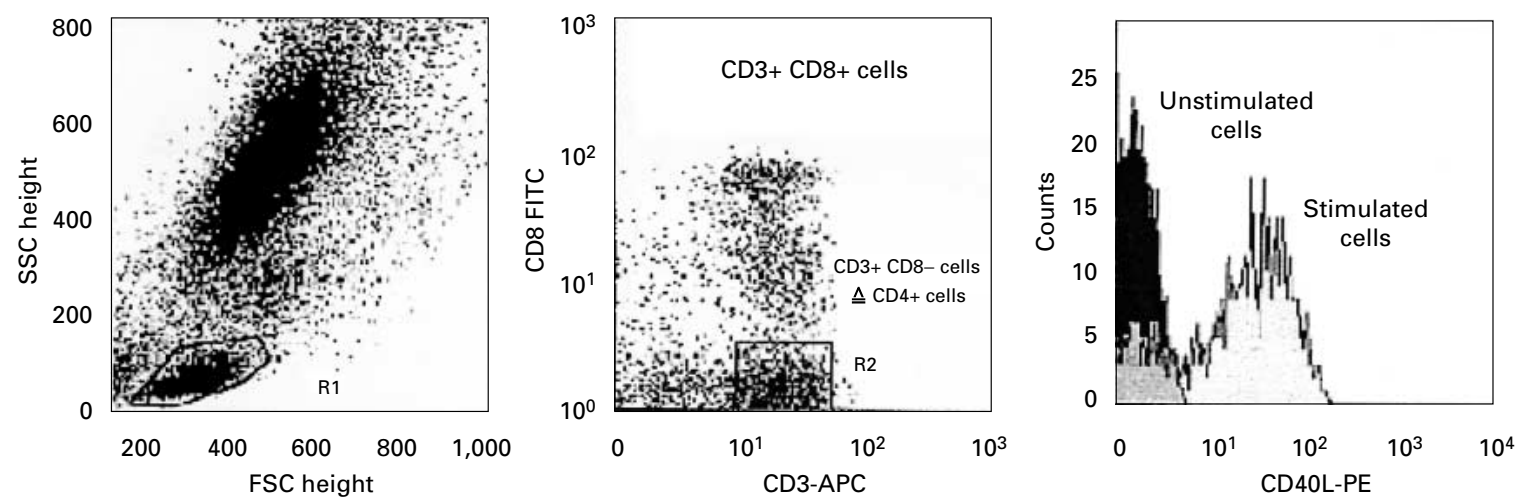

Fig. 1. FACS gating strategy on peripheral T-lymphocytes stimulated ex vivo by three-color flow cytometry (CD3-APC, CD8-FITC, CD40L-PE) shown in a healthy control. CD40L expression on CD4+ T-cells was determined by the following negative selection strategy

using two gates: the first around the lymphocyte population (FSC versus SSC, R1), the second gate around CD3+CD8- cells (correlating with CD4+ cells, R2). Events registered in R1 and R2 were analyzed for CD40L expression.

Table 3. Patient demographics of the renal transplant groups (mean $\pm \mathrm{SD}$ )

\begin{tabular}{|c|c|c|c|c|c|c|c|c|}
\hline \multirow[t]{2}{*}{ Group } & \multirow{2}{*}{$\begin{array}{l}\text { Preformed } \\
\text { antibodies } \\
\% \text { (mean) }\end{array}$} & \multicolumn{3}{|c|}{ HLA-mismatch } & \multirow{2}{*}{$\begin{array}{l}\text { Cold } \\
\text { ischemia } \\
\text { time, h }\end{array}$} & \multirow{2}{*}{$\begin{array}{l}\text { Duration } \\
\text { of dialysis } \\
\text { years }\end{array}$} & \multirow{2}{*}{$\begin{array}{l}\text { Donor } \\
\text { age } \\
\text { years }\end{array}$} & \multirow{2}{*}{$\begin{array}{l}\text { Acute rejec- } \\
\text { tion/CMV } \\
\text { infection }^{\mathrm{a}}\end{array}$} \\
\hline & & HLA-A & HLA-B & HLA-DR & & & & \\
\hline 1 & 4.2 & $0.8 \pm 0.7$ & $1.5 \pm 1.0$ & $1.3 \pm 1.0$ & $18.1 \pm 6.9$ & $4.0 \pm 3.4$ & $28.4 \pm 12.2$ & $3 / 4$ \\
\hline 1.1 & 0.0 & $0.9 \pm 0.8$ & $1.2 \pm 0.8$ & $1.1 \pm 1.0$ & $17.9 \pm 7.6$ & $4.3 \pm 3.9$ & $30.4 \pm 11.1$ & $2 / 1$ \\
\hline 1.2 & 6.0 & $0.7 \pm 0.7$ & $2.1 \pm 1.0$ & $1.6 \pm 1.0$ & $18.7 \pm 4.5$ & $3.4 \pm 1.6$ & $23.2 \pm 13.3$ & $1 / 3$ \\
\hline 2 & 5.8 & $1.2 \pm 0.8$ & $1.5 \pm 1.1$ & $1.4 \pm 0.9$ & $16.3 \pm 7.7$ & $3.8 \pm 3.5$ & $31.0 \pm 11.8$ & $5 / 2$ \\
\hline $2 \mathrm{a}$ & 4.9 & $1.5 \pm 0.6$ & $1.3 \pm 1.0$ & $1.4 \pm 0.8$ & $15.9 \pm 8.4$ & $3.9 \pm 4.0$ & $29.9 \pm 10.4$ & $3 / 0$ \\
\hline $2 b$ & 6.9 & $0.9 \pm 0.9$ & $1.8 \pm 1.1$ & $1.4 \pm 1.0$ & $16.9 \pm 6.5$ & $3.6 \pm 2.6$ & $32.5 \pm 13.2$ & $2 / 2$ \\
\hline 3 & 3.5 & $0.8 \pm 0.8$ & $1.2 \pm 0.8$ & $1.5 \pm 0.8$ & $16.8 \pm 7.7$ & $3.5 \pm 3.8$ & $40.5 \pm 14.8$ & $6 / 4$ \\
\hline $3 a$ & 0.0 & $1.1 \pm 0.7$ & $1.4 \pm 0.8$ & $1.7 \pm 0.5$ & $17.2 \pm 4.6$ & $5.0 \pm 1.7$ & $49.0 \pm 14.4$ & $2 / 1$ \\
\hline $3 b$ & 5.8 & $0.7 \pm 0.8$ & $1.1 \pm 0.9$ & $1.3 \pm 0.9$ & $16.6 \pm 9.2$ & $2.5 \pm 4.4$ & $35.1 \pm 12.4$ & $4 / 3$ \\
\hline
\end{tabular}

a Patients with acute rejection or CMV infection on the day of the study were excluded.

\section{Stimulation of Purified Cells}

Naive CD4+ T-cells were sustained by a negative isolation technique. Using antibody mix and magnetic beads (Dynabeads ${ }^{\circledR}$, Dynal, Hamburg, Germany), cytotoxic T-cells, B-cells, NK-cells and monocytes were depleted. Therefore, PBMC were obtained by FicollPaque (Amersham Pharmacia Biotech AB, Uppsala, Sweden) density centrifugation of $30 \mathrm{ml}$ peripheral blood anticoagulated with lithium heparin (1:2 in PBS). After two washing steps with $0.1 \% \mathrm{BSA} /$ PBS, the PBMC were incubated for $20 \mathrm{~min}$ at room temperature with the following antibody preparations (PharMingen, $40 \mu \mathrm{l}$ each): antiCD8 (PRA-T8), -CD14 (M5E2), -CD16 (3G8), -CD19 (HIB19), -CD56 (B159). After washing, Dynabeads ${ }^{\circledR}$ were added followed by a 15 -min incubation at $4{ }^{\circ} \mathrm{C}$. The tube was then placed in a Magnetic Particle Concentrator (Dynal) for $2 \mathrm{~min}$ and supernatant (negatively isolated CD4+ T-cells) pipetted into a fresh tube. The same procedure was applied in order to obtain CD4+ T-cells, monocytes and B-cells in one tube using only anti-CD8, -CD16 and -CD56 mAbs. Cells were stimulated by transferring $7 \times 10^{4}$ cells $/$ well $/ \mathrm{ml}$ and using different concentrations of ionomycin (0-400 ng/ml), PMA (0-100 $\mathrm{ng} / \mathrm{ml}$ ) and stimulation intervals as already described in detail.

\section{Flow Cytometric Analysis}

Data were collected with a FACSCalibur (Becton Dickinson Immunocytometry Systems, San Jose, Calif., USA) flow cytometer and analyzed by using Cellquest software (Becton Dickinson Immunocytometry Systems). 8,000 lymphocytes were counted by using a gate around the lymphocyte population on a forward scatter versus side scatter dot-plot. Another gate was set on CD3+CD8- cells (cor- 


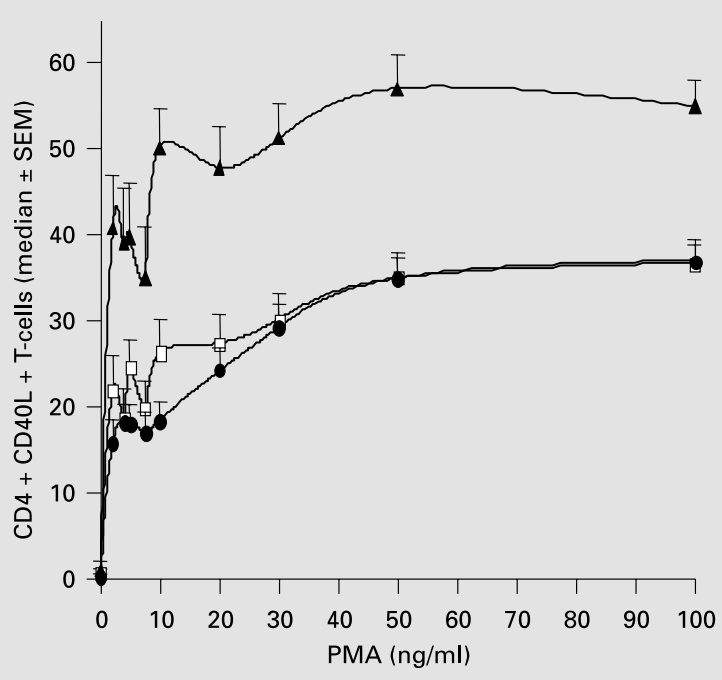

Fig. 2. Ex vivo stimulation: surface $C D 40 \mathrm{~L}$ expression of the three renal transplant groups; $\square=$ group 1, patients with excellent renal transplant function; $=$ group 2, patients with impaired graft function; $\boldsymbol{\Delta}=$ group 3 patients with chronic allograft dysfunction expressed as median \pm SEM. Whole blood was incubated with 300 $\mathrm{ng} / \mathrm{ml}$ ionomycin and different concentrations of PMA (0-100 ng/ $\mathrm{ml})$. CD4+/CD40L+ T-cells were detected by using a negative selection strategy; a subpopulation of CD3+ T-lymphocytes (CD3+CD8T-cells) was gated and CD40L expression was detected on those 'CD4+' T-cells. $p$ values at 2 ng PMA: 1 versus $3=0.0159,2$ versus $3=0.0007 ; \mathrm{p}$ values at $10 \mathrm{ng}$ PMA: 1 versus $3=0.0055,2$ versus. $3=0.0001$.

relating with $\mathrm{CD} 4+$ cells and hence termed as CD4+ cells), because PMA and ionomycin reduced the level of CD4 expressed on T-cells, preventing its use as a positive selection marker [19]. This negative selection strategy displayed the results as the percentage of CD40L+ cells that were $\mathrm{CD} 3+\mathrm{CD} 8$ - cells activated in vitro. In order to discriminate between positive and negative fluorescence, an IgG1-PE isotype control monoclonal antibody (PharMingen) was used. The cells expressing fluorescence greater than the isotype control were identified as the percentage of CD40L+ cells (fig. 1). The term CD4+/ CD40L+ describes CD4+ T-lymphocytes (setting 100\%) concomitantly expressing CD40L [20].

\section{Statistical Analysis}

All CD40L values were calculated as median \pm SEM. Differences among the results of experimental treatments were evaluated by Kruskal-Wallis and Mann-Whitney U test, performed with BMDP statistical software (BioMeDical Programs, Cork, Ireland). $\mathrm{p}<0.05$ generated at 2 and $10 \mathrm{ng}$ PMA concentrations were considered to be significant.

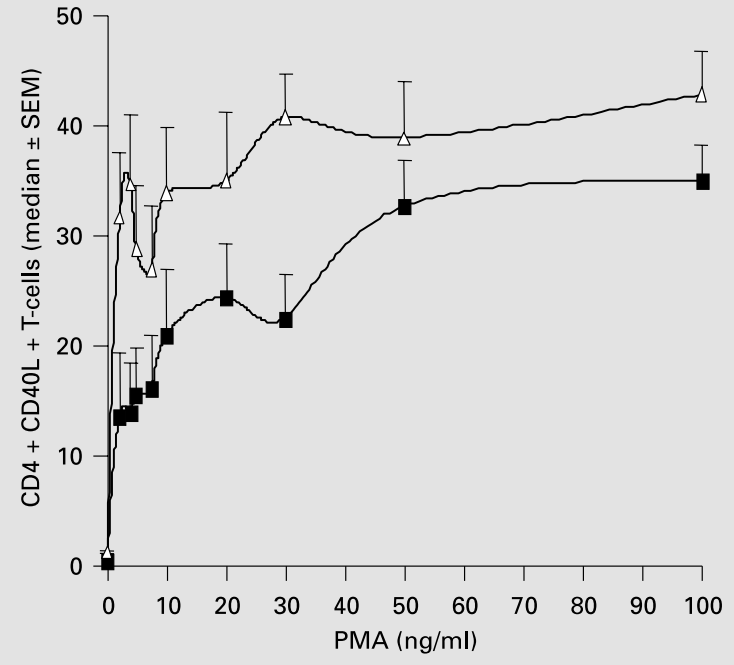

Fig. 3. CD40L expression in group 1 patients. The group was subdivided in patients who had been transplanted less than 5 years ago (group $1.1 ; \boldsymbol{\square}$ ) and those with a longer duration (group 1.2; $\triangle$ ) measured under the same conditions as depicted in figure 2 . $\mathrm{p}$ values at 2 ng PMA: 1.1 versus $1.2=0.0398$.

\section{Results}

\section{Expression of CD40L on Stimulated Peripheral}

T-Cells from Patients after Renal Transplantation

Patients with excellent and those with impaired renal graft function (groups 1 and 2) showed similar percentages of CD4+/CD40L+ cells (at $10 \mathrm{ng}$ PMA; $28.3 \pm 4.1$ and $18.4 \pm 2.4 \%$ ). Patients with chronic allograft dysfunction (group 3 ) displayed a significantly higher percentage of CD4+ lymphocytes expressing CD40L (50.1 \pm $5.0 \%, \mathrm{p}$ value $<0.01$ ) (fig. 2). Healthy controls showed similar CD40L expression patterns than group 3 patients $(40.4 \pm 3.5 \%)$. Furthermore, CD40L expression on $\mathrm{CD} 8+\mathrm{T}$ cells in patients with chronic allograft dysfunction was higher than in groups 1 and $2(9.4 \pm 1.4$ versus $7.7 \pm 0.9 \%$ and $7.2 \pm 0.5 \%, p<0.05)$. The percentage in healthy subjects was $8.9 \pm 0.6 \%$.

CD40L expression did not correlate with age, sex and the immunosuppressive regimens of transplant recipients (table 1).

\section{Subdivision of Group 1 after Transplant Duration}

In patients with stable graft function (group 1) the percentages of CD4+/CD40L+ cells stimulated ex vivo varied considerably. Thus this transplant population was 


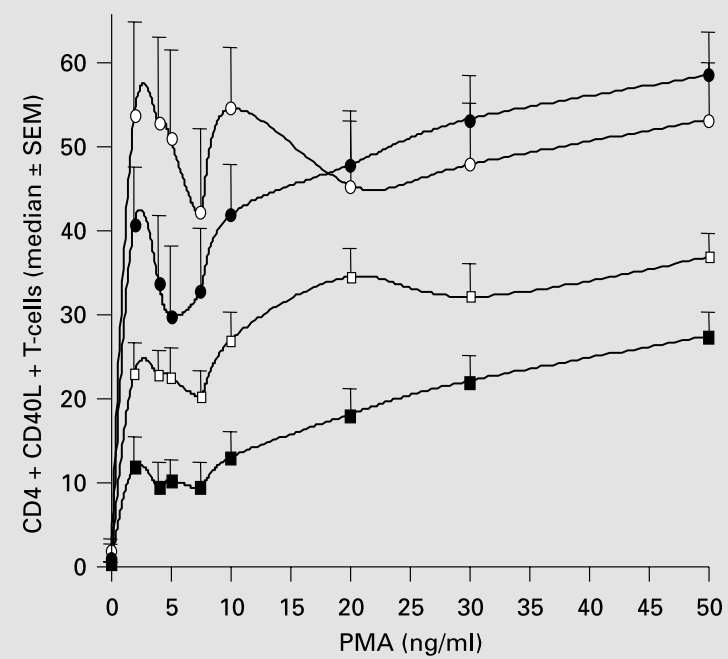

Fig. 4. Surface CD40L expression in subgroups: group $2 \mathrm{a}(\square)$ and group $3 \mathrm{a}(\mathrm{O})$ : patients with already initially raised s-crea levels and group $2 b(\boldsymbol{\square})$ and group $3 b(\bullet)$ : patients with gradually increasing s-crea. Because of a better perceptibility at lower PMA concentrations, CD4/CD40L levels were depicted only from 0 to $50 \mathrm{ng} / \mathrm{ml}$ PMA. $p$ values at 2 ng PMA: $2 \mathrm{a}$ versus $3 \mathrm{a}=0.0356,2 \mathrm{~b}$ versus $3 \mathrm{a}=$ $0.0066,2 b$ versus $3 b=0.0030 ; p$ values at 10 ng PMA: $2 a$ versus $2 b=$ $0.0322,2 \mathrm{a}$ versus $3 \mathrm{a}=0.0064,2 \mathrm{a}$ versus $3 \mathrm{~b}=0.0239,2 \mathrm{~b}$ versus $3 \mathrm{a}=$ $0.0016,2 b$ versus $3 b=0.0009$.

subdivided into two subgroups. Those patients with a graft transplanted less than 5 years ago (group 1.1, mean Tx time $3.3 \pm 1.3$ years) and those with a graft transplanted longer than 5 years ago (group 1.2, mean Tx time $10.1 \pm 4.0$ years). Whereas only a few cells were positive for CD40L in subgroup $1.1(20.9 \pm 5.9 \%)$, in group 1.2 the level increased significantly to $33.8 \pm 5.9 \%(\mathrm{p}<0.05$ at 2 ng PMA) 5 years and longer after transplantation (fig. 3).

\section{Subdivisions of Groups 2 and 3 after s-crea Increment}

Patients with impaired graft function (group 2) and patients with chronic graft dysfunction (group 3) were split up into subgroups. Patients with already initially raised s-crea levels (groups $2 \mathrm{a}$ and $3 \mathrm{a}$ ) displayed a relatively small s-crea increment during the observation time $(14.7 \pm 9.8$ and $4.2 \pm 6.4 \%)$. Those patients with a gradual s-crea increment were assigned to groups $2 \mathrm{~b}$ and $3 \mathrm{~b}$ (s-crea increment $54.2 \pm 22.3$ and $112.3 \pm 67.1 \%$ ). Patients of group 2a and 3a had a higher percentage of CD4+/CD40L+ cells $(27.0 \pm 3.2$ and $54.7 \pm 7.4)$ stimulated ex vivo than $2 \mathrm{~b}$ and $3 \mathrm{~b}$ patients $(13.0 \pm 3.1$ and 41.9

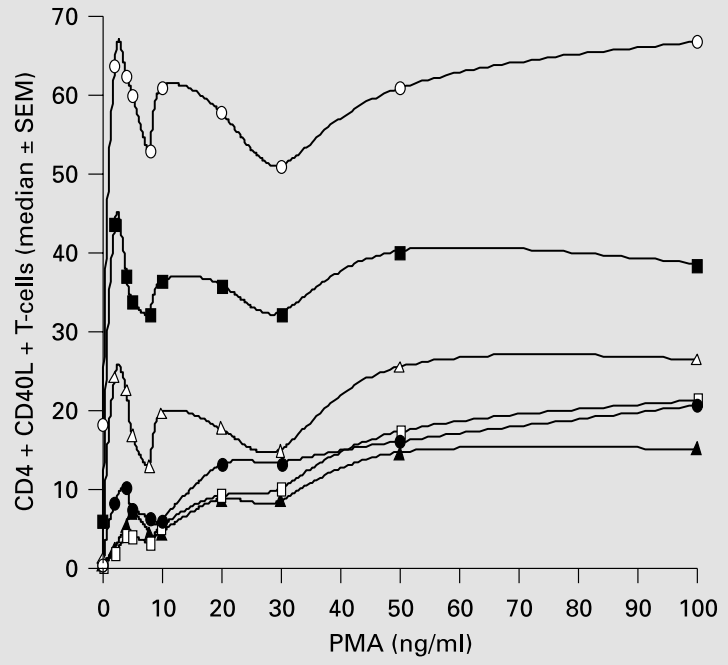

Fig. 5. CD40L expression on T-helper cells in normal subjects after ex vivo stimulation of whole blood - dose response for ionomycin. Blood was incubated at $37^{\circ} \mathrm{C}$ for $4 \mathrm{~h}$ with 6 different concentrations of ionomycin $[0(\mathbf{\Delta}), 50(\square), 100(\bullet), 200(\triangle), 300(\square)$ and $400 \mathrm{ng} / \mathrm{ml}(\mathrm{O})$ ionomycin] and 10 different concentrations of PMA.

$\pm 6.6 \%)$. Kidney graft function of patients in group 3a was considerably worse than in group $3 b$ patients, whereas there was almost no difference between group $2 \mathrm{a}$ and $2 \mathrm{~b}$ patients with regard to transplant function (table 2 , fig. 4).

\section{Different CD40L Expression on Whole Blood T-Cells,}

Purified CD4 + T-Cells and the Influence of Monocytes and B-Cells

Stimulation of T-cells in whole blood by PMA and ionomycin resulted in a distinct upregulation of CD40L expression. Ionomycin alone had almost no influence on CD40L expression in concentrations of $50-400 \mathrm{ng} / \mathrm{ml}$; in contrast, pure PMA resulted in increased expression at various concentrations $(2-100 \mathrm{ng} / \mathrm{ml})$. Depending on PMA concentrations (between 2 and $10 \mathrm{ng} / \mathrm{ml}$ PMA), a remarkable early phase decrease in CD40L expression was observed independent of ionomycin concentrations (fig. 5). Experiments with purified CD4+ T-cells (negatively selected, $85 \%$ purity) showed a strong effect of ionomycin on CD40L upregulation. A further increase in CD40L expression was accomplished by addition of PMA. The striking initial reduction of CD40L expression occurring in whole blood could also be detected on purified CD4+ T-cells (fig. 6). The influence of B-cells and 


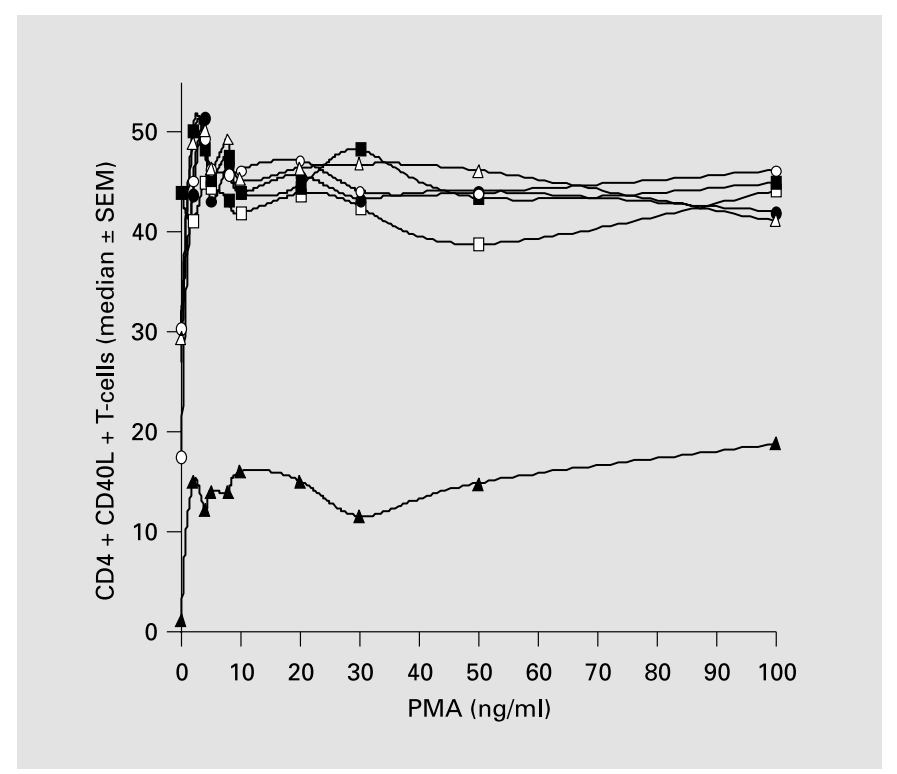

Fig. 6. Influence of PMA and ionomycin on CD40L expression on enriched peripheral CD4+ T-cells obtained from a normal subject. Enrichment was performed by negative selection strategy on PBMC using an antibody mix (anti-CD8, -CD19, -CD14, -CD16 and -CD56 $\mathrm{mAb}$ ) and Dynabeads ${ }^{\circledR}$ to deplete cytotoxic T-cells, B-cells, NK-cells and monocytes. Cells were incubated with the same concentrations of activators as in figure 5. Ionomycin concentration: $0(\boldsymbol{\Lambda}), 50(\square)$, $100(\bullet), 200(\triangle), 300(\square)$ and $400 \mathrm{ng} / \mathrm{ml}(\bigcirc)$.

monocytes was studied using PBMC purified from NKcells and cytotoxic T-cells. Depending on stimulation time, CD40L expression increased within $5 \mathrm{~h}$; a decrease was noticed thereafter (fig. 7).

\section{Discussion}

The present study demonstrates that in patients with well-functioning kidney grafts, CD40L expression on peripheral T-cells stimulated ex vivo is primarily reduced in the early course after transplantation, whereas CD40L expression is heightened in chronic renal allograft dysfunction.

The role of CD40L in the setting of kidney transplantation is ill-defined. CD40L is not present on resting T-cells; however, in vivo expression is induced by cross-linking of antigen receptors with MHC-peptide complexes on APCs. CD40L is rapidly expressed by engagement of immobilized anti-CD3 mAb to the T-cell receptor (TCR) [21]. In vitro activation of the TCR can be bypassed by ionomycin which increases the level of intracellular $\mathrm{Ca}^{2+}$ and thus

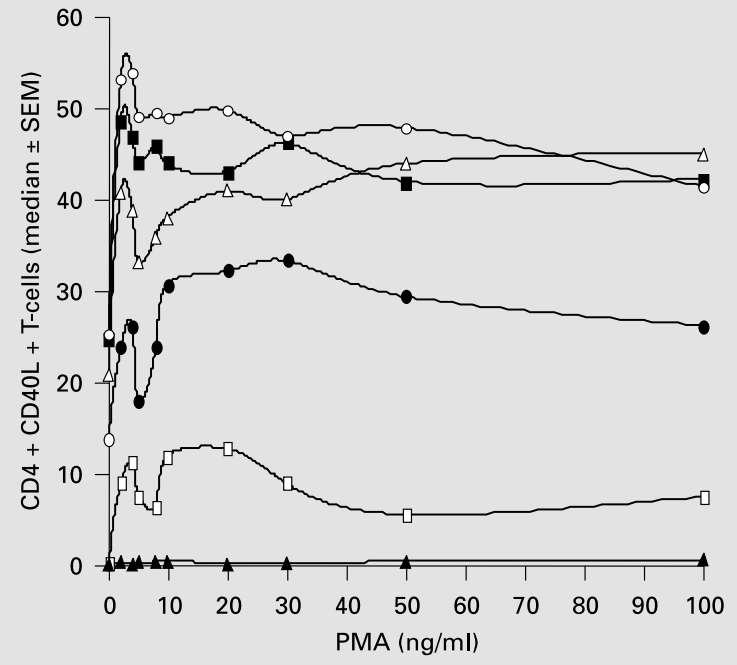

Fig. 7. Enriched CD4+ T-cells - kinetic analysis of a normal subject: Influence of B-cells and monocytes on ex vivo CD40L expression. In order to determine influence of monocytes and B-cells on CD40L expression, CD4+ T-cells were incubated with $100 \mathrm{ng} / \mathrm{ml}$ ionomycin and different concentrations of PMA $(0-100 \mathrm{ng} / \mathrm{ml})$ for $1(\boldsymbol{\Delta}), 2(\bullet)$, $3(\triangle), 4(\square), 5(\bigcirc)$ and $22 \mathrm{~h}(\square)$.

mimics the effects of inositol 1,4,5-triphosphate $\left(\mathrm{IP}_{3}\right)$ and by PMA, an activator of protein kinase C (PKC). Intracellular $\mathrm{Ca}^{2+}$ has been shown to induce high-level expression of CD40L both at the protein and the mRNA level. Additional activation of PKC by PMA results in markedly increased CD40L expression and prolongs the CD40L mRNA half-life by a mechanism which does not require de novo protein synthesis [22, 23].

Surprisingly, downregulation of CD40L expression occurred at PMA concentrations of 10 and $30 \mathrm{ng} / \mathrm{ml}$ in our study (fig. 5). Experiments with purified CD4+ T-cells (fig. 6) revealed the same effect in a diminished amount. CD40L expression on enriched CD4+ T-cells (PBMC depleted of NK-cells and cytotoxic T-cells) was determined in order to investigate the influence of B-cells and monocytes (fig. 7). As described by Yellin et al. [24] and van Kooten et al. [25], these cells are able to downregulate CD40L in a time-dependent manner in order to avoid excessive and inappropriate B- or T-cell activation. Our data support this observation. However, from our experiments, the exact mechanisms behind the apparent CD40L downregulation at 10 and $30 \mathrm{ng} / \mathrm{ml}$ PMA concentrations remain obscure. 
To our knowledge, only one study analyzed CD40L gene expression in peripheral CD4+ T-cells in the setting of acute and/or chronic renal allograft rejection [26]. The results of this study, which used the quantitative reverse transcription-polymerase chain reaction (RT-PCR) on peripheral blood CD4+ T-cells, were similar to ours. In patients with acute rejection and/or chronic allograft nephropathy (CAN), CD40L gene expression, and subsequently protein expression on peripheral CD4+ T-lymphocytes, were elevated in contrast to patients with excellent allograft function. Successful treatment of acute rejection episodes inhibited CD40L gene expression. Levels of CD40L gene expression significantly correlated with the tubular, interstitial, vascular and total acute rejection score. Nonetheless, expression levels did not correlate with any of the chronic lesions described by the Banff score system.

Several studies pointed at the crucial role of the CD40CD40L pathway in chronic allograft rejection displaying CD40-CD40L interactions in renal biopsies. Gaweco et al. [27] reported on an enhanced CD40L expression on glomerular endothelial, mesangial and epithelial cells and a moderate CD40L expression on tubular epithelial cells. Moreover, during chronic rejection, CD40+ cellular infiltrates were detected consisting of predominantly TCR- $\alpha /$ $\beta+$ T-cells and to a lesser extent CD68+ macrophages. These data imply a potential contributory role of an interaction between CD40+ graft-destructive effector cells and macrophages with CD40L+ renal allograft parenchymal cells in the development of chronic renal allograft rejection. Biancone et al. [5] observed CD40 expression on peritubular capillaries and on glomerular endothelium, whereas CD40L+CD4+ cell infiltrates were present both in the interstitium and in glomeruli. The interaction of endothelial-bound CD40 and its ligand induces endothelial cell activation. This event may possibly be involved in the pathogenesis of chronic vascular rejection [28].

In the present study we were able to demonstrate that elevated CD40L expression on CD4+ T-cells stimulated ex vivo correlated with chronic allograft dysfunction. This effect was most pronounced in patients with initial malfunction of the transplanted kidney as expressed by significantly elevated s-crea levels already 6 months after transplantation. One might assume that the biological response to immunosuppressive agents was reduced in those recipients. Interestingly, nearly half the patients with stable allograft function showed heightened CD40L expression. Most of these patients ( 7 of 11) had been transplanted more than 5 years ago. Because of the unavailability of renal allograft biopsies, we can only speculate about the underlying causes. Subclinical rejection episodes are a common phenomenon when serial biopsies are performed [29]. In one series, more than two thirds of stable grafts displayed upregulation of cytokine transcripts and histological evidence of injury. The degree of lymphocytic infiltration correlated with the degree of proteinuria and histological fibrosis. Subsequently, these patients had a significantly impaired graft function as determined by screa and GFR. Earlier studies substantiated the significant role of subclinical rejection episodes with the development of chronic pathology and late graft dysfunction [30]. With respect to the late onset of these findings we suspect, along with others [26], that nonimmunological factors such as hyperlipidemia or CNI toxicity are involved as well. In this setting, CD40L expression might indicate beginning chronic allograft nephropathy.

Our study emphasizes the important role of heightened peripheral CD40L expression on CD4+ T-lymphocytes stimulated ex vivo in the context of chronic renal allograft dysfunction. Studies with nonhuman primates blocking the CD40-CD40L or CD28/CTLA-4-B7 costimulatory pathway have revealed positive effects with respect to immunosuppressive-free graft survival [16, 31-33]. Acute rejection episodes were prevented for more than 20 months after drug withdrawal and preliminary data suggest a state of tolerance of graft-infiltrating T- and B-cells [34].

In summary, further studies are needed in order to determine whether the blockade of T-cell costimulatory pathways in humans has the power to selectively prevent transplant rejection without the need of conventional immunosuppression. The determination of CD40L expression on peripheral T-lymphocytes stimulated ex vivo might have the potential to further promote this therapeutic approach. Histopathological studies are clearly needed to clarify whether CD40L induction on peripheral T-cells is a function of transplant duration or indicates an ongoing, pronounced immune response in patients escaping the action of conventional immunosuppressive drugs.

\section{Acknowledgements}

S.L. is a recipient of grants from the Else Kröner-Fresenius Stiftung, Bad Homburg, Germany, and the Hoffmann-La Roche AG, Basel, Switzerland. 


\section{References}

1 Kasiske BL: Clinical correlates to chronic renal allograft rejection. Kidney Int Suppl 1997;63: S71-S74.

2 Gaciong Z, Koziak K, Religa P, et al: Increased expression of growth factors during chronic rejection of human kidney allograft. Transplant Proc 1995;27:928-929.

3 Suthanthiran M: Molecular analyses of human renal allografts: Differential intragraft gene expression during rejection. Kidney Int Suppl 1997;58:S15-S21.

4 Sharma VK, Bologa RM, Xu GP, et al: Intragraft TGF-beta 1 mRNA: A correlate of interstitial fibrosis and chronic allograft nephropathy. Kidney Int 1996;49:1297-1303.

5 Biancone L, Segoloni G, Turello E, et al: Expression of inducible lymphocyte costimulatory molecules in human renal allograft. Nephrol Dial Transplant 1998;13:716-722.

6 Biancone L, Donati D, Segoloni G, et al: Study of lymphocyte costimulatory molecules in renal transplantation. Transplant Proc 1998;30 2384-2386.

7 Harlan DM, Kirk AD: The future of organ and tissue transplantation: Can T-cell costimulatory pathway modifiers revolutionize the prevention of graft rejection? JAMA 1999;282: 1076-1082.

8 Sayegh MH, Turka LA: The role of T-cell costimulatory activation pathways in transplant rejection. N Engl J Med 1998;338:1813-1821.

9 Gauchat JF, Aubry JP, Mazzei G, et al: Human CD40-ligand: Molecular cloning, cellular distribution and regulation of expression by factors controlling $\mathrm{IgE}$ production. FEBS Let 1993;315:259-266.

10 Pinchuk LM, Klaus SJ, Magaletti DM, Pinchuk GV, Norsen JP, Clark EA: Functional CD40 ligand expressed by human blood dendritic cells is up-regulated by CD40 ligation. J Immunol 1996;157:4363-4370.

11 Mach F, Schonbeck U, Sukhova GK, et al Functional CD40 ligand is expressed on human vascular endothelial cells, smooth muscle cells, and macrophages: Implications for CD40-CD40 ligand signaling in atherosclerosis. Proc Natl Acad Sci USA 1997;94:19311936.

12 Gauchat JF, Henchoz S, Mazzei G, et al: Induction of human IgE synthesis in B cells by mast cells and basophils. Nature 1993;365: 340-343.

13 Gauchat JF, Henchoz S, Fattah D, et al: CD40 ligand is functionally expressed on human eosinophils. Eur J Immunol 1995;25:863-865.
14 Yellin MJ, D'Agati V, Parkinson G, et al: Immunohistologic analysis of renal CD40 and CD40L expression in lupus nephritis and other glomerulonephritides. Arthritis Rheum 1997; 40:124-134.

15 van Kooten C, Gerritsma JS, Paape ME, van Es LA, Banchereau J, Daha MR: Possible role for CD40-CD40L in the regulation of interstitial infiltration in the kidney. Kidney Int 1997; 51:711-721.

16 Kirk AD, Harlan DM, Armstrong NN, et al: CTLA4-Ig and anti-CD40 ligand prevent renal allograft rejection in primates. Proc Natl Acad Sci USA 1997;94:8789-8794.

17 Pierson RN, Chang AC, Blum MG, et al: Prolongation of primate cardiac allograft survival by treatment with ANTI-CD40 ligand (CD154) antibody. Transplantation 1999;68: 1800-1805.

18 van Kooten C: Blockade of costimulatory pathways of T-cell activation: The solution to acute and chronic rejection? Curr Opin Nephrol Hypertens 1999;8:675-680.

19 Kaldjian E, McCarthy SA, Sharrow SO, Littman DR, Klausner RD, Singer A: Nonequivalent effects of PKC activation by PMA on murine CD4 and CD8 cell-surface expression. FASEB J 1988;2:2801-2806.

20 O'Gorman MR, Zaas D, Paniagua M, Corrochano V, Scholl PR, Pachman LM: Development of a rapid whole blood flow cytometry procedure for the diagnosis of X-linked hyperIgM syndrome patients and carriers. Clin Immunol Immunopathol 1997;85:172-181.

21 Manger B, Weiss A, Imboden J, Laing T, Stobo JD: The role of protein kinase $\mathrm{C}$ in transmembrane signaling by the $\mathrm{T}$ cell antigen receptor complex. Effects of stimulation with soluble or immobilized CD3 antibodies. J Immunol 1987;139:2755-2760.

22 Nusslein HG, Frosch KH, Woith W, Lane P, Kalden JR, Manger B: Increase of intracellular calcium is the essential signal for the expression of CD40 ligand. Eur J Immunol 1996;26:846850 .

23 Suarez A, Mozo L, Gayo A, Zamorano J, Gutierrez C: Requirement of a second signal via protein kinase $\mathrm{C}$ or protein kinase $\mathrm{A}$ for maximal expression of CD40 ligand. Involvement of transcriptional and posttranscriptional mechanisms. Eur J Immunol 1997;27:2822-2829.

24 Yellin MJ, Sippel K, Inghirami G, et al: CD40 molecules induce down-modulation and endocytosis of T cell surface $T$ cell-B cell activating molecule/CD40-L. Potential role in regulating helper effector function. J Immunol 1994;152: 598-608.
25 van Kooten C, Gaillard C, Galizzi JP, et al: B cells regulate expression of CD40 ligand on activated $\mathrm{T}$ cells by lowering the mRNA level and through the release of soluble CD40. Eur J Immunol 1994;24:787-792.

26 Shoker A, George D, Yang H, Baltzan M Heightened CD40 ligand gene expression in peripheral CD4+ $\mathrm{T}$ cells from patients with kidney allograft rejection. Transplantation 2000;70:497-505

27 Gaweco AS, Mitchell BL, Lucas BA, McClatchey KD, Van Thiel DH: CD40 expression on graft infiltrates and parenchymal CD154 (CD40L) induction in human chronic rena allograft rejection. Kidney Int 1999;55:15431552.

28 Hollenbaugh D, Mischel-Petty N, Edwards CP et al: Expression of functional CD40 by vascular endothelial cells. J Exp Med 1995;182:3340.

29 Rush DN, Karpinski ME, Nickerson P, Dancea S, Birk P, Jeffery JR: Does subclinical rejection contribute to chronic rejection in renal transplant patients? Clin Transplant 1999;13:441446.

30 Kirk AD, Jacobson LM, Heisey DM, Radke NF, Pirsch JD, Sollinger HW: Clinically stable human renal allografts contain histological and RNA-based findings that correlate with deteriorating graft function. Transplantation 1999 ; 68:1578-1582.

31 Ossevoort MA, Ringers J, Boon L, et al: Blocking of costimulation prevents kidney graft rejection in rhesus monkeys. Transplant Proc 1998;30:2165-2166.

32 Kawai T, Abrahamian G, Sogawa H, et al: Costimulatory blockade for induction of mixed chimerism and renal allograft tolerance in nonhuman primates. Transplant Proc 2001;33: 221-222.

33 Cho CS, Burkly LC, Fechner JH Jr, et al: Successful conversion from conventional immunosuppression to anti-CD154 monoclonal antibody costimulatory molecule blockade in rhesus renal allograft recipients. Transplantation 2001;72:587-597.

34 Kirk AD: Immunosuppression without immunosuppression? How to be a tolerant individual in a dangerous world: Transpl Infect Dis 1999; $1: 65-75$. 